\title{
Quality of life in a sample of Egyptian renal transplant recipients
}

\author{
Amany Haroun El Rasheed ${ }^{1}$, Essam Khedr ${ }^{2}$, Rehab Naguib ${ }^{1 *}$ (D), Maissa Eid ${ }^{1}$, Hussien Elkholy ${ }^{1}$ and Samah Rabie ${ }^{3}$
}

\begin{abstract}
Background: Poor quality of life has been reported after renal transplantation.

So, we aimed to identify the quality of life and its demographic and clinical correlates among Egyptian renal transplant recipients.

A cross-sectional observational study of 230 post-renal transplantation recipients (PRTRs) who were recruited from Ain Shams University Specialized Hospital and Nasser Institute nephrology clinics. All cases were subjected to a designed questionnaire for PRTRs, the semi-structured questionnaire for renal transplant recipients and the Arabic version of the World Health Organization Quality of Life Questionnaire (WHOQOL-100).

Results: All the PRTRs had unsatisfactory social quality of life (QoL) while $97.8 \%$ had unsatisfactory overall QoL; moreover, $92.6 \%$ were not satisfied as regards environmental and independence QoL. Psychological dissatisfaction was met in $75.7 \%$ of all subjects, whereas the least dissatisfaction rate was the spiritual QoL (15.2\%). Younger age groups were the most who complained of unsatisfactory quality of life in all domains except the spiritual QoL. All domains of QoL were found not statistically associated with gender, marital status, or social class. Subjects who received higher education had better psychological and independence QoL. The overall QoL and physical QoL were found to be correlated only with age. The psychological and independence QoL were positively correlated with age, sex, educational level, and occupation while the environmental QL was found to be positively correlated with occupation.

Conclusion: The prevalence of unsatisfactory quality of life is quite high among PRTRs. Our findings pointed to the need of recognizing quality of life among renal transplant recipients, and we suggest that mental health professionals should be included in the multidisciplinary team.
\end{abstract}

Keywords: Quality of life, Renal transplantation, Renal transplant recipients

\section{Background}

The World Health Organization defined quality of life (QoL) as "the individual's perception of their life status concerning the context of culture and value system in which they live and their goals, expectations, standards, and concerns" [1]. It is thus a concept that entails several meanings and relates to the individual's level of satisfaction in different spheres of life [2, 3]. Quality of life can be assessed using both general and specific instruments [4].

\footnotetext{
*Correspondence: rehab.naguib@gmail.com; Rehab_naguib@med.asu.edu.eg ${ }^{1}$ Institute of Psychiatry, Ain Shams University, Cairo, Egypt

Full list of author information is available at the end of the article
}

Kidney transplantation is the treatment of choice for patients suffering from end-stage renal disease (ESRD), with recipients experiencing increased longevity and improved quality of life relative to patients on dialysis [5]. It is expected that in successful transplantation, the recipient's QoL improves in all aspects [6], yet since the first organ transplantation in the 1950s, there have been reports that patients who underwent organ transplantation had a poor quality of life and prognosis if they were depressed and/or anxious prior to transplantation [7]. Psychiatric disorders such as depression and anxiety may be seen after a successful renal transplantation, and
Springer Open

(c) The Author(s). 2020 Open Access This article is licensed under a Creative Commons Attribution 4.0 International License, which permits use, sharing, adaptation, distribution and reproduction in any medium or format, as long as you give appropriate credit to the original author(s) and the source, provide a link to the Creative Commons licence, and indicate if changes were made. The images or other third party material in this article are included in the article's Creative Commons licence, unless indicated otherwise in a credit line to the material. If material is not included in the article's Creative Commons licence and your intended use is not permitted by statutory regulation or exceeds the permitted use, you will need to obtain permission directly from the copyright holder. To view a copy of this licence, visit http://creativecommons.org/licenses/by/4.0/. 
its frequency is quite higher in renal transplantation patients in comparison to others [8].

Health-related quality of life (HRQOL) has become recognized as an important outcome measure in patients with organ transplantation. Successful renal transplantation provides a better patient outcome in terms of HRQOL. Evidence shows that HRQOL of renal transplant recipients improved significantly when compared with their HRQOL in the preoperative dialysis period [9]. The improvement in HRQOL after renal transplantation may be attributable to many factors, such as effective functioning of renal graft, fewer medical complications, and lifestyle changes. On the other hand, there are several factors in renal transplant recipients which have a negative impact on HRQOL [10]. This includes fear of rejection, the immune-suppressive therapy, and the shifts in family dynamics and the emotional difficulties from coping problems and readjustment into the society $[11,12]$.

The psychological profile of kidney transplant recipients indicates higher levels of depression, anxiety, and an overall lower quality-of-life score relative to the greater population [13]. Furthermore, adult kidney transplant recipients score lower than the general population on health-related quality-of-life assessments in physical and emotional capacity, overall health, vitality, and social functioning $[14,15]$.

\section{Rationale of the study}

Despite the fact that PRTRs were estimated to have a better QoL after the operation, most studies done on that patient groups found that a low level of QoL was observed.

This research is a part of a series of research done to evaluate Egyptian renal transplant recipients in multiple aspects [16].

This cross-sectional observational study aimed to identify the quality of life among renal transplant recipients and its psycho demographic and clinical correlates.

The study was approved by the ethical committee of Ain Shams University, and also approvals and ethical clearance were obtained from the authority of the two selected hospitals.

\section{Methods}

\section{Subjects}

The study was conducted at the nephrology clinic of Ain Shams University Specialized Hospital and Nasser Institute, where patients were followed up after undergoing surgery. Renal transplant recipients coming for follow up were recruited. The study sample was a stratified random sample. The sample size was calculated by statistician using Epi-Info program version 6 and the expected prevalence accordingly is $18.4 \%$. Therefore, the sample size was calculated to be 230 subjects.

\section{Methods}

Cases were collected from the nephrology clinics of Nasser Institute on Saturdays and Wednesdays every week and from the nephrology clinics of Ain Shams University Specialized Hospital that were held from Saturday to Wednesday after obtaining relevant authority permission. There were no inclusion or exclusion criteria. A written consent was taken from the patients before they participated in the study, and confidentiality was ensured and explanation of nature of the research was done.

In a session of $3 \mathrm{~h}$, all cases were subjected to the following:

(1) A designed questionnaire: a simple questionnaire was designed including yes/no, multiple choice questions, and closed-ended questions based on the sheet of the Institute of Psychiatry, Ain Shams University, and it assess the domains of age, sex, occupation, education, social class, and marital status.

(2) The semi-structured questionnaire for renal transplant recipients: a semi-structured questionnaire based on the Structured Interview for Renal Transplantation SIRT [17] to determine the medical condition of the PRTRs and the circumstances of surgery.

(3) The Arabic version of the World Health Organization Quality of Life Questionnaire (WHOQOL-100): [18] it is a cross-cultural measurement tool to examine overall quality of life and general health perceptions. The Arabic translation was translated and validated by the Faculty of Medicine, Alexandria University.

\section{Statistical analysis}

The results were analyzed using the statistical package for the social sciences [19]. Qualitative data were described using frequency and percentage while quantitative data were described using mean and standard deviation. Continuous variables were compared using the Student's $(t$ test) and chi-square to compare categorical variables. Pearson's $(r)$ correlation was used for correlation of variables. A statistical level of significance was set at 0.05 .

\section{Results}

\section{Description of the study sample}

The study investigated 230 patients: 165 (72\%) males and $65(28 \%)$ females; their mean age was $37.3 \pm 7.6$ years. The majority belonged to low middle social class category. Most of them were married and received considerable education with $23 \%$ of the sample unemployed 
and about $8 \%$ housewives. The length of hemodialysis therapy before renal transplantation ranged from 1 to 7 years. As regards the transplant, $30 \%$ received the renal graft from a relative donor, whereas $70 \%$ received it from non-relative donors. The time elapsed since the surgery was ranging from 3 to 18 months. In all cases, the operations were sponsored by the government or insurance.

\section{Quality of life among post-renal transplant recipients (PRTRs)}

All the PRTRs had unsatisfactory social QoL while 97.8\% had unsatisfactory overall QoL. Moreover, 92.6\% were not satisfied as regards environmental and independence QoL. Psychological dissatisfaction was met in $75.7 \%$ of all subjects, whereas the least dissatisfaction rate was the spiritual QoL 15.2\% (Fig. 1).

\section{Age}

Younger age groups were the most who complained of unsatisfactory quality of life in all domains except the spiritual QoL. Patients from 40 to 50 years were the least dissatisfied in all domains except the spiritual one (Fig. 2).

Table 4 shows that there is a significant negative correlation between age of recipients with physical, psychological, independence, and overall domains of quality of life $(P>0.05)$.

\section{Sex, marital status, and social class}

All domains of QoL were found not statistically associated with gender, marital status, or social class (Table 1).

The correlation between the PRTRs and gender is displayed in Table 4. It indicates that sex was correlated only with the independence and psychological aspects of QoL.

\section{Education}

Subjects who received higher education as bachelor or high institute and also those who received secondary school education had better psychological and independence QoL than the other types of educational level. Other domains of QoL as physical, social, and environmental showed no significant differences as regards types of education received.

There is significant positive correlation between psychological and independence, QoL with the education received by the recipients Table 4 .

\section{Occupation}

Table 2 shows that the type of job has a significant relationship with QoL domains. The unsatisfactory physical QoL was more significantly encountered among the unemployed patients (96.2\%) and least among the housewives (61\%). Subjects who were unskilled laborers were the commonest who had unsatisfactory psychological QoL (84.4\%).

The worse scores in the independence 0QoL were among those who were unemployed (85\%). On the other hand, the least scores were encountered in housewives.

There is a significant correlation between the type of job with the independence and environmental QoL (Table 4).

\section{Medical variables}

Studying different medical variables in relation to QoL domains revealed non-significant relation between

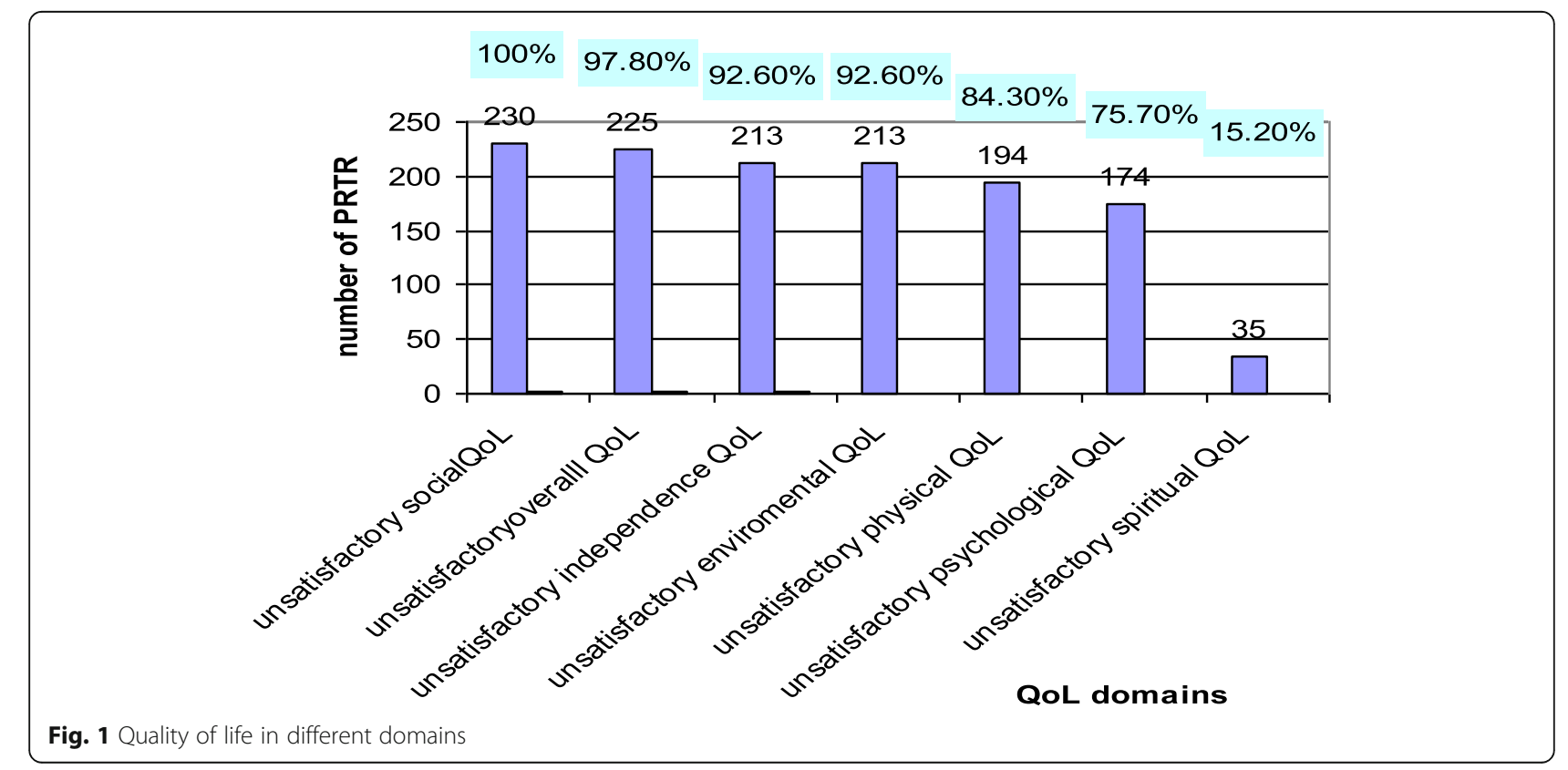




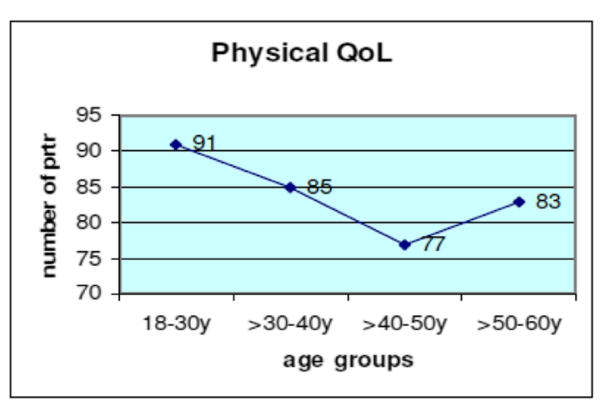

a:

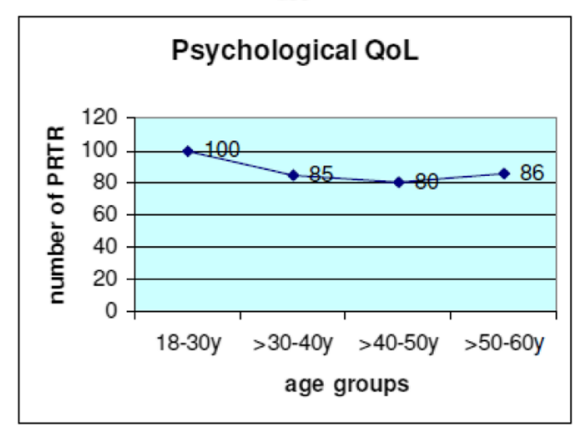

b:

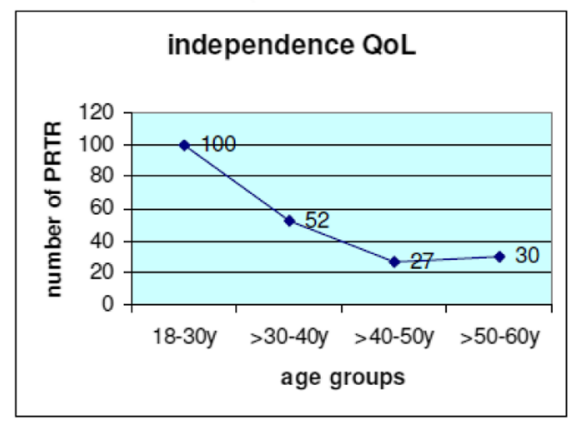

c:

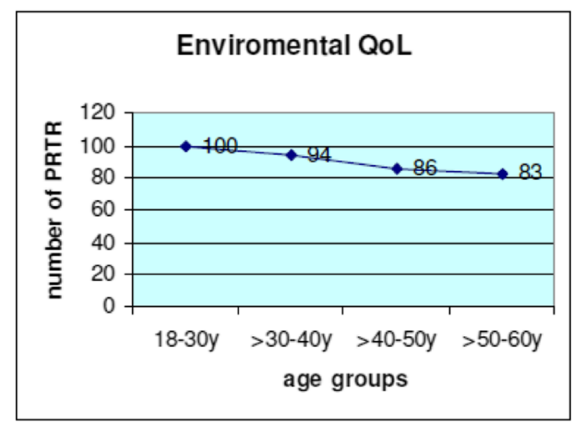

d:

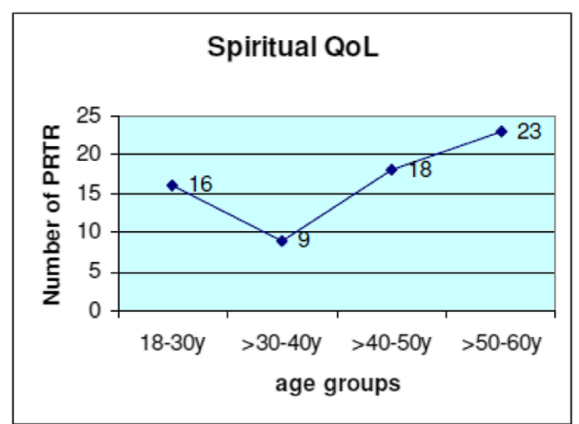

Fig. 2 Different domains of unsatisfactory quality of life in relation to age groups

duration of hemodialysis, medical comorbidity, side effects of received medication, time elapsed since the transplantation operation, or the type of donors with different domains of QoL (Table 3).

\section{Quality of life correlation with different variables}

The overall QoL and physical QoL were found to be correlated only with age. Whereas psychological and independence QoL were correlated with age, sex, educational level, and occupation while the environmental QoL was found to be correlated with occupation (Table 4).

\section{Discussion}

Renal transplantation is the only effective treatment in end-stage renal disease, which provided better wellbeing but at the same time triggers numerous psychological implications [20-22]. There is variation in the quality of life, coping, and psychiatric morbidity among renal transplant recipients [12].

QoL refers to the social, physical, and psychological domains of health, which influenced by the patient's perception of the culture and value system [23], and in relation to his goals and expectation [21].

Thus, evaluation of the QoL in PRTRs has been considered as an important way to determine the impact of transplantation operation on those patients [24].

This study was dedicated to exploring the quality of life and its correlates among Egyptian renal transplant recipients. The study revealed that PRTRs had unsatisfactory social QoL, and the majority had unsatisfactory overall, independence, environmental, physical, and psychological aspects of QoL. We are in contrast with previous investigators who reported better QoL after the operation in Bangladesh and India [12, 25]. In another community [26], a study also reported improvement of 
Table 1 Quality of life among PRTRs in relation to sex, marital status, and social class

\begin{tabular}{|c|c|c|c|c|c|c|}
\hline \multirow[t]{2}{*}{ WHOQoL-100 } & \multicolumn{5}{|l|}{ Sex } & \multirow[t]{2}{*}{$P$} \\
\hline & & $\begin{array}{l}\text { Males } \\
n=165\end{array}$ & $\begin{array}{l}\text { Females } \\
n=65\end{array}$ & & & \\
\hline \multirow[t]{2}{*}{ Physical } & Poor & $131(79.3 \%)$ & 63(96.9\%) & & & \multirow[t]{2}{*}{$>0.05$} \\
\hline & Good & $34(20.6 \%)$ & $2(3 \%)$ & & & \\
\hline \multirow[t]{2}{*}{ Psychological } & Poor & $113(68.4 \%)$ & $61(93.8 \%)$ & & & \multirow[t]{2}{*}{$>0.05$} \\
\hline & Good & $48(29 \%)$ & $4(6 \%)$ & & & \\
\hline \multirow[t]{2}{*}{ Social } & Poor & 165(100\%) & $65(100 \%)$ & & & \multirow[t]{2}{*}{$>0.05$} \\
\hline & Good & $0(0 \%)$ & $0(0 \%)$ & & & \\
\hline \multirow[t]{2}{*}{ Independence } & Poor & $87(52.7 \%)$ & $43(66.1 \%)$ & & & \multirow[t]{2}{*}{$>0.05$} \\
\hline & Good & $72(43.6 \%)$ & $22(33.8 \%)$ & & & \\
\hline \multirow[t]{2}{*}{ Environmental } & Poor & 150(90.9\%) & 63(96.9\%) & & & \multirow[t]{2}{*}{$>0.05$} \\
\hline & Good & $15(9 \%)$ & $2(3 \%)$ & & & \\
\hline \multirow[t]{2}{*}{ Spiritual } & Poor & $26(15.7 \%)$ & $9(13.8 \%)$ & & & \multirow[t]{2}{*}{$>0.05$} \\
\hline & Good & 139(84.2\%) & $54(83 \%)$ & & & \\
\hline \multirow[t]{2}{*}{ Overall } & Poor & 159(96.3\%) & $62(95.3 \%)$ & & & \multirow[t]{2}{*}{$>0.05$} \\
\hline & Good & $6(3.6 \%)$ & $3(4.6 \%)$ & & & \\
\hline \multirow[t]{2}{*}{ WHOQOL100 } & Marital & & & & & \multirow[t]{2}{*}{ P } \\
\hline & & $\begin{array}{l}\text { Single } \\
n=54\end{array}$ & $\begin{array}{l}\text { Married } \\
n=168\end{array}$ & $\begin{array}{l}\text { Divorced } \\
n=5\end{array}$ & $\begin{array}{l}\text { Widow } \\
n=3\end{array}$ & \\
\hline \multirow[t]{2}{*}{ Physical } & Poor & 49(90.7\%) & $142(84.5 \%)$ & $2(40 \%)$ & 1(33.3\%) & \multirow[t]{2}{*}{$>0.05$} \\
\hline & Good & $5(9.3 \%)$ & $26(15.5 \%)$ & $3(60 \%)$ & $2(66.7 \%)$ & \\
\hline \multirow[t]{2}{*}{ Psychological } & Poor & $36(66.7 \%)$ & 136(80.9\%) & $2(40 \%)$ & $0(0 \%)$ & \multirow[t]{2}{*}{$>0.05$} \\
\hline & Good & 18(33.3\%) & $32(19.1 \%)$ & $3(60 \%)$ & $3(100 \%)$ & \\
\hline \multirow[t]{2}{*}{ Social } & Poor & $54(100 \%)$ & $168(100 \%$ & $5(100 \%)$ & $3(100 \%)$ & $>0.05$ \\
\hline & Good & $0(0 \%)$ & $0(0 \%)$ & $0(0 \%)$ & $0(0 \%)$ & \\
\hline Independence & Poor & 38(70.3\%) & $91(54.2 \%)$ & $2(40 \%)$ & $0(0 \%)$ & $>0.05$ \\
\hline & Good & 16(29.7\%) & $9(5.8 \%)$ & $3(60 \%)$ & $3(100 \%)$ & \\
\hline Environmental & Poor & $50(92.5 \%)$ & 158(94\%) & $4(80 \%)$ & 1(33.3\%) & $>0.05$ \\
\hline & Good & $4(7.5 \%)$ & $10(6 \%)$ & $1(20 \%)$ & $2(66.7 \%)$ & \\
\hline Spiritual & Poor & 10(18.5\%) & $25(14.8 \%)$ & $0(0 \%)$ & $0(0 \%)$ & $>0.05$ \\
\hline & Good & $44(82.5 \%)$ & 143(85.2\%) & $5(100 \%)$ & $3(100 \%)$ & \\
\hline Overall & Poor & $51(94.4 \%)$ & 166(98.8\%) & $4(80 \%)$ & $2(66.7 \%)$ & $>0.05$ \\
\hline & Good & $3(5.6 \%)$ & $2(1.2 \%)$ & $1(20 \%)$ & 1(33.3\%) & \\
\hline WHOQOL100 & Social & & & & & P \\
\hline & & $\begin{array}{l}\text { Very low } \\
n=10\end{array}$ & $\begin{array}{l}\text { Low } \\
n=110\end{array}$ & $\begin{array}{l}\text { Low middle } \\
n=110\end{array}$ & & \\
\hline Physical & Poor & $7(70 \%)$ & $90(81.8 \%)$ & $97(88.2 \%)$ & & $>0.05$ \\
\hline & Good & $3(30 \%)$ & $20(18.2 \%)$ & 13(11.8\%) & & \\
\hline Psychological & Poor & $3(30 \%)$ & $83(75.55 \%)$ & $88(80 \%)$ & & $>0.05$ \\
\hline & Good & $7(70 \%)$ & $27(24.5 \%)$ & $22(20 \%)$ & & \\
\hline Social & Poor & 10(100\%) & $110(100 \%)$ & $110(100 \%)$ & & $>0.05$ \\
\hline & Good & $0(0 \%)$ & $0(0 \%)$ & $0(0 \%)$ & & \\
\hline Independence & Poor & $5(50 \%)$ & $56(50.9 \%)$ & $70(63.6 \%)$ & & $>0.05$ \\
\hline & Good & $5(50 \%)$ & $54(49.1 \%)$ & 40(36.4\%) & & \\
\hline Environmental & Poor & $8(80 \%)$ & $101(91.8 \%)$ & $104(94.5 \%)$ & & $>0.05$ \\
\hline
\end{tabular}


Table 1 Quality of life among PRTRs in relation to sex, marital status, and social class (Continued)

\begin{tabular}{lllll}
\hline \multirow{3}{*}{ Spiritual } & Good & $2(20 \%)$ & $9(8.2 \%)$ & $6(5.5 \%)$ \\
& Poor & $0(0 \%)$ & $10(9.1 \%)$ & $25(22.8 \%)$ \\
Overall & Good & $10(100 \%)$ & $100(90.9 \%)$ & $85(77.2 \%)$ \\
& Poor & $9(90 \%)$ & $106(96.3 \%)$ & $108(98.2 \%)$ \\
& Good & $1(10 \%)$ & $4(3.7 \%)$ & $2(1.8 \%)$ \\
\hline
\end{tabular}

QoL in all of his patients by using a multidimensional

QoL scale (WHOQL Brief).

Our finding was in congruence with another study by Beard [27] who reported that QoL is seriously affected by transplant operation, and another study by Johnson et al. [28] also highlighted that African American PRTRs achieve less improvement in QoL than Caucasian Americans.

Table 2 Quality of life among PRTRs in relation to educational level and occupation

\begin{tabular}{|c|c|c|c|c|c|c|c|c|}
\hline \multirow[t]{2}{*}{ WHOQOL100 } & \multicolumn{7}{|c|}{ Education } & \multirow[t]{2}{*}{$P$} \\
\hline & & $\begin{array}{l}\text { Uneducated } \\
n=41\end{array}$ & $\begin{array}{l}\text { Primary } \\
n=25\end{array}$ & $\begin{array}{l}\text { Preparatory } \\
n=44\end{array}$ & $\begin{array}{l}\text { Secondary } \\
n=54\end{array}$ & $\begin{array}{l}2 \text { years institute } \\
n=20\end{array}$ & $\begin{array}{l}\text { Bachelor } \\
n=66\end{array}$ & \\
\hline \multirow[t]{2}{*}{ Physical } & Poor & 40(97.6\%) & $22(88 \%)$ & $37(84 \%)$ & $47(87 \%)$ & 17(95\%) & $31(67.3 \%)$ & \multirow[t]{2}{*}{$>0.05$} \\
\hline & Good & $1(2.4 \%)$ & $3(12 \%)$ & $7(16 \%)$ & $3(13 \%)$ & $3(5 \%)$ & 15(33.7\%) & \\
\hline \multirow[t]{2}{*}{ Psychological } & Poor & $40(97.6 \%$ & 19(76\%) & $41(93.1 \%)$ & $31(57.4 \%)$ & 14(70\%) & $29(63 \%)$ & \multirow[t]{2}{*}{$<0.05$} \\
\hline & Good & $1(2.4 \%)$ & $6(24 \%)$ & $3(6.9 \%)$ & $19(42.5 \%)$ & $6(30 \%)$ & $17(37 \%)$ & \\
\hline \multirow[t]{2}{*}{ Social } & Poor & $41(100 \%$ & $25(100 \%)$ & $44(100 \%)$ & $54(100 \%)$ & $20(100 \%)$ & $46(100 \%)$ & \multirow[t]{2}{*}{$>0.05$} \\
\hline & Good & $0(0 \%)$ & $0(0 \%)$ & $\mathrm{O}(0 \%)$ & $\mathrm{O}(0 \%)$ & $0(0 \%)$ & $0(0 \%)$ & \\
\hline \multirow[t]{2}{*}{ Independence } & Poor & $23(56 \%)$ & $16(64 \%)$ & $25(56.8 \%)$ & $30(55.5 \%)$ & $11(55 \%)$ & $26(56.5 \%)$ & \multirow[t]{2}{*}{$<0.05$} \\
\hline & Good & 18(44\%) & $9(36 \%)$ & $19(43.2 \%)$ & $24(44.5 \%)$ & $9(45 \%)$ & $20(43.5 \%)$ & \\
\hline \multirow[t]{2}{*}{ Environmental } & Poor & 39(95\%) & 23(92\%) & $37(84 \%)$ & $51(94.4 \%)$ & $20(100 \%)$ & 43(93.4\%) & \multirow[t]{2}{*}{$>0.05$} \\
\hline & Good & $2(5 \%)$ & $2(8 \%)$ & $7(16 \%)$ & $3(5.6 \%)$ & 0 & $3(6.6 \%)$ & \\
\hline \multirow[t]{2}{*}{ Spiritual } & Poor & 10(24.3\%) & $4(16 \%)$ & $5(11.3 \%)$ & $8(14.8 \%)$ & $3(15 \%)$ & $5(10.8 \%)$ & \multirow[t]{2}{*}{$>0.05$} \\
\hline & Good & $31(75.6 \%)$ & $21(84 \%)$ & 29(88.7\%) & $44(85.2 \%)$ & 17(85\%) & $41(89.2 \%)$ & \\
\hline \multirow[t]{2}{*}{ Overall } & Poor & $31(75.6 \%)$ & 24(96\%) & 43(97.7\%) & $52(96.2 \%)$ & 19(96\%) & 45(97.8\%) & \multirow[t]{2}{*}{$>0.05$} \\
\hline & Good & $10(24.3 \%)$ & $1(4 \%)$ & $1(2.3 \%)$ & $2(3.8 \%)$ & $1(4 \%)$ & $1(2.2 \%)$ & \\
\hline \multirow{2}{*}{$\begin{array}{l}\text { WHO } \\
\text { QoL } \\
100\end{array}$} & \multicolumn{7}{|c|}{ Occupational levels } & \multirow[t]{2}{*}{$P$} \\
\hline & & $\begin{array}{l}\text { Unemployed } \\
n=53\end{array}$ & $\begin{array}{l}\text { Unskilled } \\
n=58\end{array}$ & $\begin{array}{l}\text { Semi-skilled } \\
n=26\end{array}$ & $\begin{array}{l}\text { Semi-professional } \\
n=50\end{array}$ & $\begin{array}{l}\text { Professional } \\
n=25\end{array}$ & $\begin{array}{l}\text { House wives } \\
n=18\end{array}$ & \\
\hline \multirow[t]{2}{*}{ Physical } & Poor & $51(96.2 \%$ & 49(84.4\%) & $23(88.4 \%)$ & $43(86 \%)$ & $17(68 \%)$ & $11(61 \%)$ & \multirow[t]{2}{*}{$<0.01$} \\
\hline & Good & $2(3.8 \%)$ & $9(15.6 \%)$ & $3(11.6 \%)$ & $7(14 \%)$ & $8(32 \%)$ & 7(39\%) & \\
\hline \multirow[t]{2}{*}{ Psychological } & Poor & $41(77.3 \%$ & 49(84.4\%) & $19(73 \%)$ & $41(82 \%)$ & $13(52 \%)$ & $11(61 \%)$ & \multirow[t]{2}{*}{$<0.01$} \\
\hline & Good & $12(32.3 \%)$ & $9(15.6 \%)$ & $7(27 \%)$ & $9(18 \%)$ & $12(48 \%)$ & 7(39\%) & \\
\hline \multirow[t]{2}{*}{ Social } & Poor & $53(100 \%)$ & $58(100 \%)$ & $26(100 \%)$ & $50(100 \%)$ & $25(100 \%)$ & 18(100\%) & \multirow[t]{2}{*}{$<0.05$} \\
\hline & Good & $0(0 \%)$ & $0(0 \%)$ & $0(0 \%)$ & $0(0 \%)$ & $0(0 \%)$ & $0(0 \%)$ & \\
\hline \multirow[t]{2}{*}{ Independence } & Poor & $45(85 \%)$ & $31(53.4 \%)$ & $8(30.7 \%)$ & $31(62 \%)$ & $12(48 \%)$ & $4(22.2 \%)$ & \multirow[t]{2}{*}{$<0.01$} \\
\hline & Good & $8(15 \%)$ & $27(46.6 \%)$ & 18(69.3\%) & 19(38\%) & 13(52\%) & $14(77.8 \%)$ & \\
\hline \multirow[t]{2}{*}{ Environmental } & Poor & 49(92.4\%) & $55(94.8 \%)$ & $25(96.1 \%)$ & $44(88 \%)$ & 23(92\%) & $17(94.4 \%)$ & $<0.01$ \\
\hline & Good & $4(7.6 \%)$ & $3(5.2 \%)$ & $1(3.9 \%)$ & $6(12 \%)$ & $2(8 \%)$ & $1(5.6 \%)$ & \\
\hline Spiritual & Poor & 10(18.8\%) & $4(6.8 \%)$ & $7(27 \%)$ & $10(20 \%)$ & $2(8 \%)$ & $2(11.1 \%)$ & $<0.01$ \\
\hline & Good & $43(81.2 \%)$ & $54(93.2 \%)$ & 19(73\%) & $40(80 \%)$ & 23(92\%) & 16(88.9\%) & \\
\hline Overall & Poor & $51(96.2 \%)$ & $57(98.2 \%)$ & 25(96.1\%) & 49(98\%) & 24(96\%) & 17(94.4\%) & $>0.05$ \\
\hline & Good & $2(3.8 \%)$ & $1(1.8 \%)$ & $1(3.9 \%)$ & $1(2 \%)$ & $1(4 \%)$ & $6(5.6 \%)$ & \\
\hline
\end{tabular}




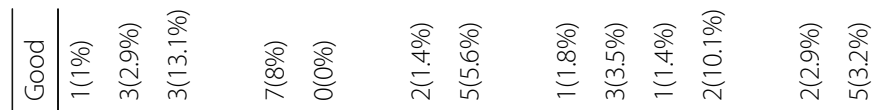

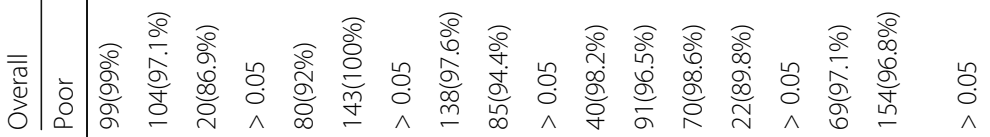

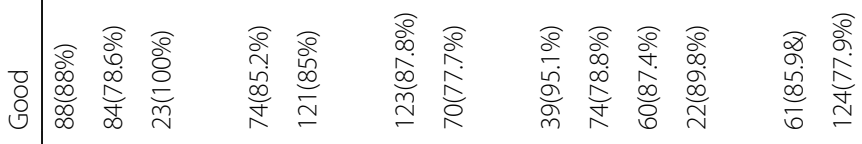

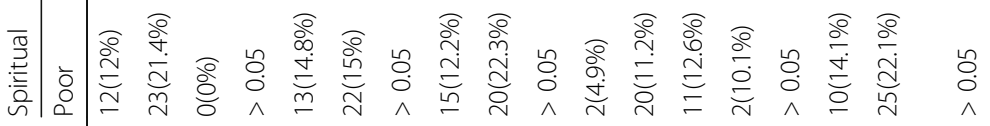

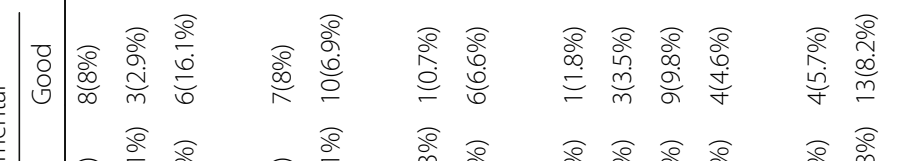

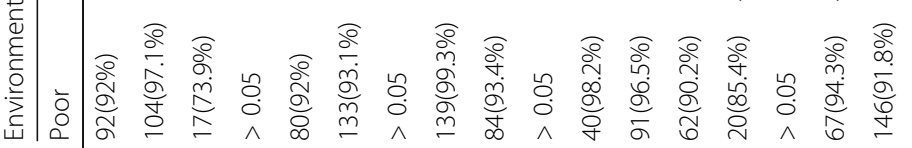

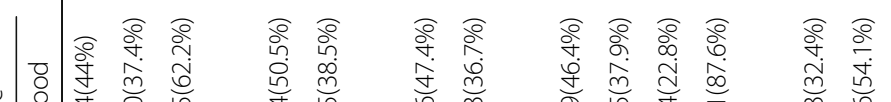

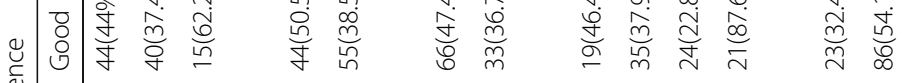

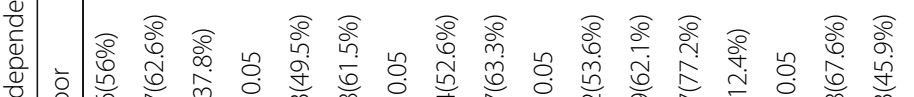

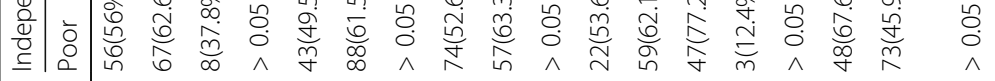

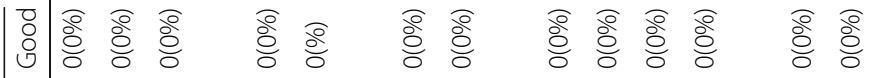

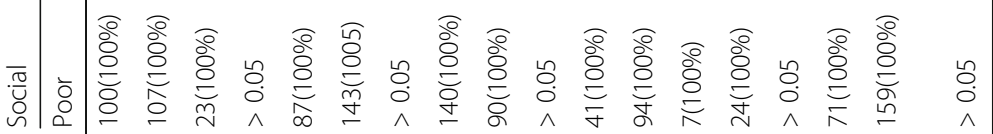

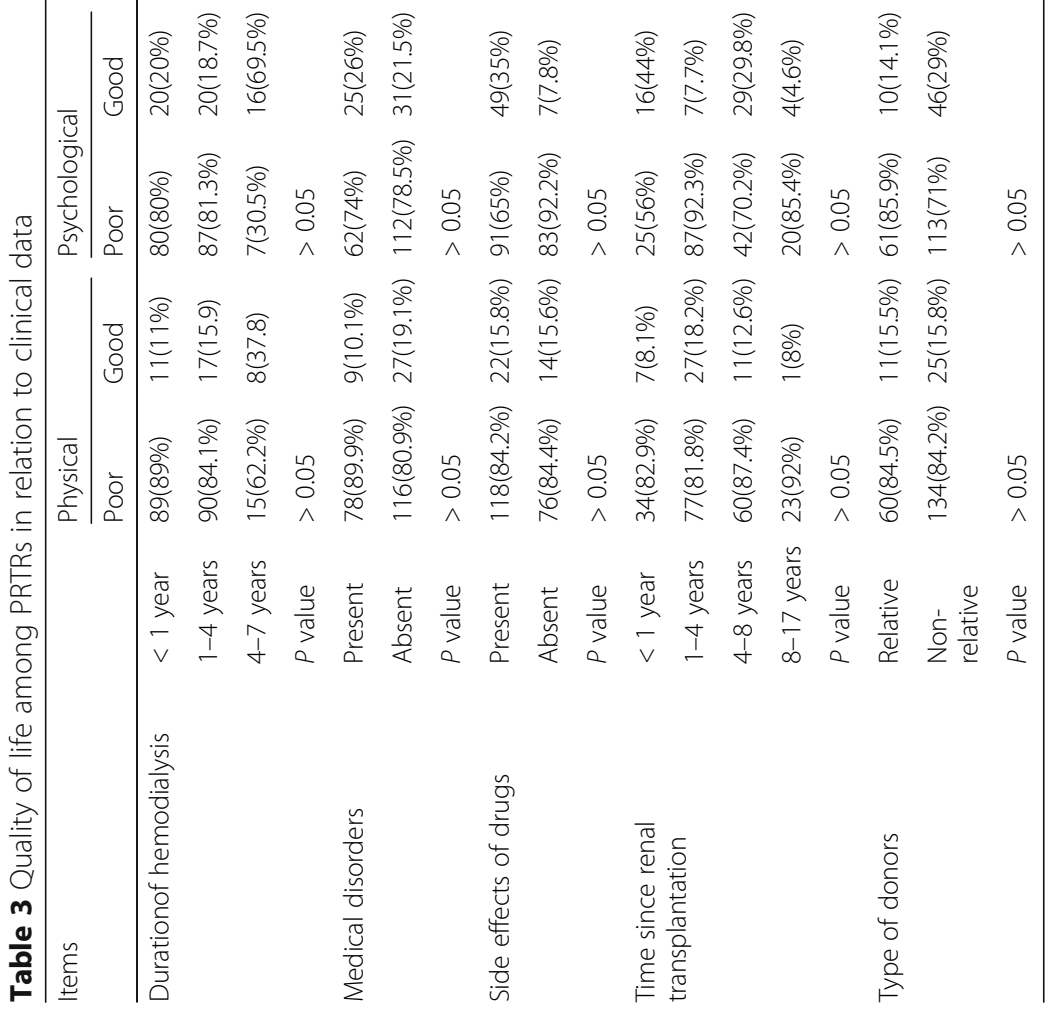


Table 4 Correlation between quality of life domains with sociodemographic and some clinical variables

\begin{tabular}{|c|c|c|c|c|c|c|c|c|c|c|c|c|c|c|}
\hline \multirow[t]{2}{*}{ Items } & \multicolumn{2}{|l|}{ Age } & \multicolumn{2}{|l|}{ Sex } & \multicolumn{2}{|c|}{$\begin{array}{l}\text { Educational } \\
\text { level }\end{array}$} & \multicolumn{2}{|c|}{ Occupation } & \multicolumn{2}{|c|}{ Social class } & \multicolumn{2}{|c|}{$\begin{array}{l}\text { Duration of } \\
\text { hemodialysis }\end{array}$} & \multicolumn{2}{|c|}{$\begin{array}{l}\text { Time since renal } \\
\text { transplantation }\end{array}$} \\
\hline & $r$ & $P$ & $r$ & $P$ & $r$ & $P$ & $r$ & $P$ & $r$ & $P$ & $r$ & $P$ & $r$ & $P$ \\
\hline Physical QoL & 0.29 & $<0.05$ & 0.16 & $>0.05$ & 0.16 & $>0.05$ & 1.1 & $>0.05$ & 0.04 & $>0.05$ & -0.14 & $>0.05$ & 0.40 & $>0.05$ \\
\hline Psychological QoL & 0.30 & $<0.05$ & -0.5 & $<0.01$ & -0.5 & $<0.01$ & 1.4 & $>0.05$ & 0.11 & $>0.05$ & -0.02 & $>0.05$ & -0.12 & $>0.05$ \\
\hline Social QoL & -0.15 & $>0.05$ & 0.17 & $>0.05$ & 0.17 & $>0.05$ & 1.3 & $>0.05$ & -0.06 & $>0.05$ & 0.06 & $>0.05$ & 0.16 & $>0.05$ \\
\hline Interdependence Qol & 0.29 & $<0.05$ & 0.26 & $<0.05$ & 0.26 & $<0.05$ & 3.6 & $<0.05$ & 0.10 & $>0.05$ & 0.21 & $>0.05$ & 0.11 & $>0.05$ \\
\hline Environmental QoL & 0.12 & $>0.05$ & 0.10 & $>0.05$ & 0.10 & $>0.05$ & 2.9 & $<0.05$ & 0.10 & $>0.05$ & 0.10 & $>0.05$ & 0.11 & $>0.05$ \\
\hline Spiritual QoL & 0.15 & $>0.05$ & -0.19 & $>0.05$ & -0.19 & $>0.05$ & 1.6 & $>0.05$ & 0.13 & $>0.05$ & 0.12 & $>0.05$ & 0.17 & $>0.05$ \\
\hline Overall QoL & 0.34 & $<0.05$ & -0.14 & $>0.05$ & -0.14 & $>0.05$ & 1.9 & $>0.05$ & 0.13 & $>0.05$ & 0.22 & $>0.05$ & 0.21 & $>0.05$ \\
\hline
\end{tabular}

The life after kidney transplantation is a life with uncertainty [12]. There is unrealistic expectation which lowered the perception of the transplant receipts of their quality of life and made them less satisfied with the outcome. Moreover, the transplant recipients have to cope with fear of death, fear from graft's rejection, and fear from non-return to work. Thus, they suffer from damage to their self-esteem in that their relationships with significant people are reduced to hostile and/or dependent attachments [29].

Another factor contributed to the poor quality of life is the need of receiving immunosuppressive medication with adverse side effects [22].

\section{Sociodemographic variables}

Long-term QoL in recipients depends on many factors include the subject's age, education received, marital condition, living situation, and employment [6].

\section{Age}

In our study, age was negatively correlated with QoL, the younger age group had unsatisfactory QoL in all domains except the spiritual one. They had more worry regarding the future graft, their life is never anxiety-free, and their continuous concern about body functions triggers an intense fear which impacts their QoL $[22,30]$.

There is variation in the relation between age and QoL in the PRTRs, while Shah et al. 2006 [31] have reported that QoL in PRTRs was not correlated with age, and other study in Thai society found that the older recipients had unsatisfactory QoL due to their inability to carry out various activities [32]. The differences in this data may be related to the trans-cultural differences or the tools used.

\section{Gender}

It was found that gender was not related to QoL. Our findings yielded support to previous data reported by several researches [20,32-34]. It is contrary to that of Johnson who reported poor QoL among men [28].

\section{Marital status}

There was no relationship between QoL and marital status. This may reflect that care giving in Egyptian families may be carried out via the extended families. The same findings were found in Indian community [35].

\section{Level of education}

We found positive correlation of satisfactory QoL with the years of education received. This may be due to the impact of learning on development of coping strategies.

Tennen and Affleck [36] stated that low education and the perception of medical care as being a substantial economic burden predict poor coping and independence and poorer functional status; moreover, Eryilmaz et al. [37] found that lower education is considered as negatively effective factor on the QoL of PRTRs.

\section{Employment}

The unsatisfactory QoL was found more among the unemployed and unskilled laborers with significant correlation with independence and environmental domains of QoL.

\section{Medical data}

Despite that different publications [4, 30] have proved that medical comorbidity, side effects of immune suppressant drugs, duration of hemodialysis prior to the operation or time elapsed since the surgery, and type of donors may affect the recipients QoL, yet we did not find such relation in our PRTRs. The difference may be related to different sample or tools used.

\section{QoL domains}

In concordance with previous study, we proved that physical QoL was correlated significantly with age [38]. The psychological and independence QoL were correlated with age, sex, education level, and occupation. These findings may point that those patients may feel less positive about themselves. 


\section{Conclusion}

Despite that renal transplantation is the only potentially curative treatment for end-stage renal failure; it was found that quality of life become poorer after renal transplantation in almost all domains.

We highlighted some associated sociodemographic and clinical factors; thus, our findings pointed to the need of recognizing quality of life and its psychosocial correlates among renal transplant recipients.

Accordingly, the multidisciplinary team should integrate mental health professionals to encourage the patients for better coping.

\section{Strength and limitation}

The strength of this study is attributed to being one of the few studies in Egypt addressing the QoL after renal transplant operation; however, it is limited by the crosssectional design and the limited recruitment from only two governmental hospitals which limit the generalizability of the obtained data.

We did not highlight the risk factors, and we also did not explore some variables as past psychiatric history, coping strategies, and perceived social support. These points should be taken into consideration in future research.

\section{Abbreviations}

ESRD: End-stage renal disease; HRQOL: Health-related quality of life; PRTRs: Post-renal transplantation recipients; QoL: Quality of Life; WHOQOL100: The World Health Organization Quality of Life Questionnaire

\section{Acknowledgements}

This study could not be completed without the support of Prof. Naglaa EIMahalawy, Professor of Psychiatry, Ain Shams University. We also thank Prof. AfafHamed Khalil Professor of Psychiatry, Ain Shams University for her support.

\section{Authors' contributions}

A.H. and E.K.: supervision and revision of data. H.E. and M.E.: design of the work and data analysis. S.R.: patients interviewing, data collection. R.N.: interpretation of data. All authors have read and approved the manuscript.

\section{Funding}

No funds.

\section{Availability of data and materials}

Data is available

\section{Ethics approval and consent to participate}

The research was approved by the ethical committee of Ain Shams University with reference number FWA 00006444. Also, detailed written consent was obtained from all subjects, and all of them had the right to withdraw anytime during the research without affection of their treatment or the given service.

\section{Consent for publication \\ Done}

\section{Competing interests}

The authors declare that they have no competing interests.

\section{Author details}

${ }^{1}$ Institute of Psychiatry, Ain Shams University, Cairo, Egypt. ${ }^{2}$ Faculty of Medicine, Renal Department, Ain Shams University, Cairo, Egypt. ${ }^{3}$ Misr University of Science and Technology, Cairo, Egypt.

Received: 11 June 2020 Accepted: 18 June 2020

Published online: 11 August 2020

\section{References}

1. Fleck MPA, Louzada S, Xavier M, Chachamovich E, Vieira G, Santos L, Pinzon V (2000) Aplicação da versãoemportuguês do instrumentoabreviado de avaliação de qualidade de Vida - WHOQOL-bref 2000. Rev SaúdePública 34:178-183

2. Minayo MCS, Hartz ZMA, Buss PM (2000) Qualidade de vidaemsaúde: um debate necessário 2000. CiêncSaúdeColetiva 5:7-18

3. Roncada C, Mattiello R, Pitrez PM, Sarria EE (2013) Specific instruments to assess quality of life in children and adolescents with asthma. J Pediatr 89(3):217-225

4. Bittencourt Z, de Camargo Z, Filhoa G, Mazzalia M and dos Santosb (2004) Quality of life in renal transplant patients: impact of a functioning graft. Rev Saude Publica. 38(5):732-734 https://doi.org/10.1590/s003489102004000500018. Epub 18 Oct 2004

5. White C, Gallagher P (2010) Effect of patient coping preferences on quality of life following renal transplantation. J Adv Nurs 66(11):2550-2559

6. Neipp M, Karavul B, Jackobs S (2006) Meyer zuVilsendorf A, Richter N, Becker T, et al. Quality of life in adult transplant recipients more than 15 years after kidney transplantation. Transplantation 81:1640e4

7. Illescas-Rico R, Amaya-Ayala F, Jimenez-Lopez JL, Caballero-Mendez ME, Gonzalez-Llaven J (2002) Increased incidence of anxiety and depression during bone marrow transplantation. Arch Med Res 33(2):144-147

8. Arapaslan B, Soykan A, Soykan C, Kumbasar H (2004 Jun) Cross-sectional assessment of psychiatric disorders in renal transplantation patients in Turkey: a preliminary study. Transplant Proc 36(5):1419-1421

9. Liu HX, Lin J, Lin XH, Wallace L, Teng S, Sp Z, Hao YF (2015) Quality of sleep and health-related quality of life in renal transplant recipients. Int J ClinExp Med 8(9):16191-16198

10. Cameron Jl, Whiteside C, Katz J, Devins GM (2000) Differences in quality of life across renal replacement therapies: a meta-analytic comparison. Am J Kidney Dis 35:629-637

11. Morris PJ (2001) Kidney transplantation: principles and practice. Philadelphia: W.B. Saunders Company

12. Das RC, Srivastava K, Tudu J, Hooda AK (2014) Crosssectional study of quality of life after renal transplant in end stage renal disease. Ind Psychiatry J 23(1):40-43

13. De Pasquale C, Pistorio ML, Veroux P, Giuffrida G, Sinagra N, Ekser B, Veroux M (2011) Quality of life in kidney transplantation from marginal donors. Transplant Proc 43(4):1045-1047. https://doi.org/10.1016/j.transproceed.2011. 01.156

14. Aaseboe W, Homb-Vesteraas N, Hartmann A, Stavem K (2009) Life situation and quality of life in young adult kidney transplant recipients. Nephrol Dial Transplant 24(1):304-308

15. WHO. Bibliography on Transplantation \& Ethics. WHO publications, Geneva, Switzerland. 27 August 2004; Version 2.0.

16. El Mahalawy N, Hatata HA, El Meguid MA, Moneim DA, El Din MH, Rabei SH (2017) Correlates of psychiatric morbidity in Egyptian renal transplant recipients. Middle East Curr Psychiatry 24:85-92

17. Mori DL, Gallacher P, Milne J. Structured interview for renal transplantation SIRT. Psychosomatics 41:5 September October 2000.

18. WHOQOL Group. Field Trial WHOQOL-100 facet definitions and questions. Geneva: WHO (MNH/PSF/95.1.B), 1995.

19. Inc SPSS (2003) SPSS statistics for windows. SPSS Inc., Chicago, IL

20. Jofrè R, López-Gómez JM, Moreno F, Sanz-Guajardo D, Valderrábano F (1998) Changes in quality of life after renal transplantation. Am J Kidney Dis 32:93-100

21. Jana AK, Sircar D, Waikhom R, Praharaj SK, Pandey R, RayChaudhury A, Dasgupta S (2014 Sep-Oct) Depression and anxiety as potential correlates of post-transplantation renal function and quality of life. Indian J Nephrol. 24(5):286-290

22. Naqvi R (2015) Evaluation of psychiatric issues in renal transplant setting. Indian J Nephrol 25(6):321-325 
23. Franke GH, Heemann U, Kohnle M, Luetkes P, Maehner N, Reimer J (2000) Quality of life in patients before and after kidney transplantation. Psychol Health 14:1037-1049

24. Costa JM, Nogueira LT (2014) Association between work, income and quality of life of kidney transplant recipient the municipality of Teresina, PI. Brazil J Bras Nefrol 36(3):332-338

25. Hossain MR, Iqbal MM, Alam MR, Islam SF, Faroque MO, Selim IS. Quality of life in renal transplant recipient and donor. Transplant Proc. 2015 May; 4 7(4):1128-1130.

26. Lazzaretti CT, Carvalho JG, Mulinari RA, Rasia JM (2004) Kidney transplant improves multidimensional quality of life. Transplant Proceedings 36(4):872873

27. Beard BH (1971) The quality of life before and after renal transplantation Diseases of the Nervous System 32(1):24-31

28. Johnson CD, Wicks MN, Milstead J, Hartwig M, Hathaway DK (1998) Racial and gender differences in quality of life following kidney transplantation. Image J Nurs Sch 30(2):125-130 (ISSN: 0743-5150)

29. Cianciaruso B, Gallo R, Nappi R, Crispo A, Pisani A, Sabbatini M, Federico S (2008) Renal transplantation and sleep: anew life is not enough. J Nephrol 21:97-101

30. Dew MA (1998) Quality-of-life studies: organ transplantation as an exemplar of past progress and future directions. J Psychosom Res 14(2):189-195

31. Shah VS, Ananth A, Sohal GK, Bertges-Yost W, Eshelman A, Parasuraman RK, Venkat KK (2006) Quality of life and psychosocial factors in renal transplant recipients. Transplant Proc:1283-1285 (ISSN: 0041-1345)

32. Junchotikul P, Charoenthanakit C, Saiyud A, Parapiboon W, Ingsathit A, Jirasiritham S, Sumethkul V (2015) Assessment of the changes in healthrelated quality of life after kidney transplantation in a cohort of 232 Thai patients. Transplant Proc 47:1732e1735

33. Hathaway DK, Winsett AP, Peters TG (1987) Psychological assessment in renal transplant recipients. Dialysis and Transplantation 16:442-444

34. Garth K. Weight gain during the first year following renal transplantation. www.utmem.edu/nursing/faculty.staff/documents/cowan_patty2008.pdf

35. Jadhav BS, Dhavale HS, Dere SS, Dadarwala DD (2014) Psychiatric morbidity, quality of life and caregiver burden in patients undergoing hemodialysis. Med J DY PatilUniv 7:722-727

36. Tennen H, Affleck G. Positive change following adversity: In search of meticulous methods. In Positive Life Changes in the Context of Physical Illness, ed. C Park, S Lechner, AL Stanton, MH Antoni. Washington, DC: Am. Psychol. Assoc. In press, 2006.

37. Eryilmaz MM, Ozdemir C, Yurtman F, Cilli A, Karaman T (2005) Quality of sleep and quality of life in renal transplantation patients. Transplant Proc 37(5):2072-2076

38. Tanriverdi N, Ozçürümez G, Colak T, Dürü C, Emiroğlu R, Zileli L, Haberal M (2004 Jan-Feb) Quality of life and mood in renal transplantation recipients, donors, and controls: preliminary report. Transplant Proc 36(1):117-119

\section{Publisher's Note}

Springer Nature remains neutral with regard to jurisdictional claims in published maps and institutional affiliations.

\section{Submit your manuscript to a SpringerOpen ${ }^{\circ}$ journal and benefit from:}

- Convenient online submission

- Rigorous peer review

- Open access: articles freely available online

- High visibility within the field

- Retaining the copyright to your article

Submit your next manuscript at $\boldsymbol{\nabla}$ springeropen.com 